ACTA THERIOLOGICA

Vol. 29, 1: 3-16, 1984

\title{
Body and Skeleton Growth in Laboratory Field Voles of Different Seasonal Generations
}

Galina A. KLEVEZAL, Michalina PUCEK \& Evgenija P. MALAFEeVA

\begin{abstract}
Klevezal G. A., Pucek M. \& Malafeeva E. F., 1984: Body and skeleton growth in laboratory field voles of different seasonal generations. Acta theriol., 29, 1: 3-16 [With 2 Tables \& 6 Figs.]

Studies were made of the body and skeleton growth of field voles, Microtus agrestis (Linnaeus, 1761), born in spring $(\mathrm{n}=66)$ and in autumn $(n=33)$ in a laboratory colony. All the voles were weighed weekly. Each month 5 spring and 4 autumn voles were taken at random, injected with tetracycline hydrochloride (TH) in doses of $20 \mathrm{mg} / \mathrm{kg}$ of body weight, and killed 15 days later. Bone increments of different parts of the mandible, humerus and femur of TH-labelled voles were measured on cross-sections in ultraviolet light, and the mean increment for all bones was calculated as the bone growth index. Differences were found in the skeleton growth of voles of the two seasonal generations studied: individuals born in spring grew faster, but for a shorter period than those born in autumn. A similar pattern of body weight growth was poorly expressed. Periods of skeleton growth in the field voles were followed by periods of retardation or cessation of growth. There was no synchronous cessation of bone growth in winter in laboratory field voles, but two periods of bone growth acceleration were found in voles in both seasonal generations: one clearly expressed in November and a fainter one in January. Such growth acceleration is probably determined by exogenous factors.

[Kolcov's Inst. of Developmental Biology, USSR Acad. Sci., 26 Vavilov Str., 117334 Moscow, USSR (GAK, EPM), and Mammals Res. Inst., Polish Acad. Sci., 17-230 Białowieża, Poland (MP)]
\end{abstract}

\section{INTRODUCTION}

A large number of authors have drawn attention to differences in the rate of growth of body weight in rodents of different seasonal generations (for review see, e.g. Schwarz et al., 1964, and also Zejda, 1971, Adamczewska-Andrzejewska, 1973, Mina \& Klevezal, 1976, Pokrovskij \& Bol'shakov, 1979). In the majority of cases it is clear that individuals of spring generations have a far more rapid growth rate than individuals of autumn generations, and quickly reach the weights of adult animals, after which their growth rate declines. Individuals born in autumn grow more slowly and reach adult weights over a period almost twice longer than for those born in spring. These differences have been observed under both laboratory and natural conditions.

The body weight of growing animals reflects changes connected with skeleton growth, increase in muscular mass etc. Since, however, it is 
the sum of the weight of many components, it is burdened with considerable error as the result of, for instance, the different degree of fatness of the animals, particularly those kept in captivity. It would therefore appear that skeleton growth is a better measure of the animals' growth rate. By administering in vivo tetracycline as a marker of the growth of growing bones, it is possible to analyze such changes not only in experimental medicine (Hansson, 1974) but also in ecological studies (Klevezal \& Gębczyński, 1978, Klevezal \& Mina, 1980), and thus it is a convenient method for research of this type.

The purpose of this study was to trace and compare changes in body weight and rate of skeletal growth with age in $M$. agrestis born in different seasons, but living under fairly constant laboratory conditions.

\section{MATERIAL AND METHODS}

The term seasonal generation used here refers to the group of animals born during the same season. In our case these were field voles, Microtus agrestis (Linnaeus, 1761), born in spring from 28th March to 28th April $1980(n=66)$, and in autumn, from 5th August to 24th September, $1980 \quad(n=39)$, under laboratory conditions. Voles of the two generations originated from the same pairs of parents. The animals were marked by toe-clipping and were taken from their mother at the age of approximately 4 weeks. Males and females were kept separately, in warmed accommodation (winter and summer the average temperature varied from 18 to $20^{\circ} \mathrm{C}$ ) with natural light. The basic food consisted of oats and beet, and in summer freshly-mown grass was added. The experiment lasted to May 1981.

All the animals were weighed in the morning before feeding, on a defined day of the week, hence the voles' age on the weighing day have differed by $2-3$ days. Body weights were analyzed at 2-week intervals.

Starting from the age of one month five spring generation and 4 autumn generations animals monthly were given a single intramuscular injection of tetracycline (teracycline hydrochloridae - TH) in doses of $20 \mathrm{mg} / \mathrm{kg}$ of body weight. On the fifteenth day after injection the animals were anaesthetized with chloroform and fixed in $70 \%$ ethyl alcohol. Three bones were taken for examination of skeleton growth: mandible, humerus and femur. The bones were cleaned of soft tissue, dried and embedded in polyether resin. Cross-sections were cut with a diamond saw and ground on frosted glass with a grinding powder to $25-50$ micron thickness. Ground sections were examined in ultraviolet light under a compound microscope and dissecting microscope. Bone tissue increments, from the bright yellow tetracycline line to bone edge, were measured by means of an ocular micrometer, and expressed in relative units of the ocular scale.

As the deposit of appositional bone layers is uneven, a series of measurements was made on a given cross-section in places of maximum and minimum increments from different sides of the bone. For instance, bone increments were measured on the mandible from the buccal and lingual sides of cross-sections from the toothless part (Fig. 1A) and the ramus of the mandible (Fig. 1D), and additionally on the lower margin on cross-sections of the mandibular shaft in the anterior (Fig. 1B) and posterior part (Fig. 1C) (a total of 20 measurements). Calculation 
were made for each bone surface of mean minimum and maximum increments, and then mean increments for all planes of the cross-section, totalled and treated as mean increment of the mandible.

Increments of the femur and humerus were determined on three cross-sections, passing through the middle of the shaft, and its distal and proximal part. On each cross-section measurement was made on two axes vertical to each other of bone increments from the periostal and endostal sides (Fig. 1E). The mean value of all measurements $(8 \times 3=24)$ for the given bone was treated as the mean increment of this bone.
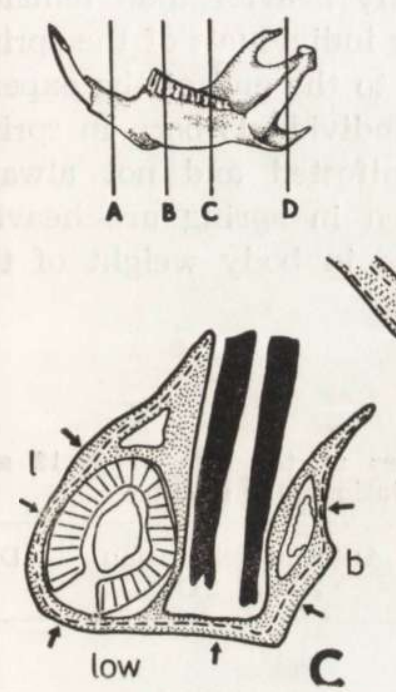

Fig. 1. Cross-section planes of the mandible in voles (A, B, C, D) and places in which bone increments were measured on ground sections (indicated by arrows). E - way in which measurements were made on the cross-section of femur or humerus. 1 - lingual side, b - buccal side, low - lower margin of corpus mandibulae. Dashed line means tetracycline line.

Relative increment of an individual bone was calculated as a ratio of the mean increment of the given bone to the maximum mean increment for this bone in our study. Its value varied within the range from 0.0 to 1.0 .

The total of relative increments calculated for the mandible, humerus and femur, was used as an index of skeleton growth.

Mean specific growth rate of the body weight $(C)$ was calculated as the growth rate over a 2-week period after the Schmalhausen formula for daily growth' (cf. Schmalhausen, 1935):

$$
C=\frac{\log W_{2}-\log W_{1}}{\left(t_{2}-t_{1}\right) 0.4343}
$$

where $W_{1,2}=$ body weight in grams at the beginning and end of the growth period, and $t_{1,2}=$ age in days. 
3. RESULTS

\subsection{Changes with Age in Body Weight}

Values of the SD of body weight variation curves with changing age of voles point to the very great individual variability occurring in all age groups (Fig. 2). After the age of one week distinct sex dimorphism is evident. During the first weeks of life females of both generations are heavier than males, but this alters at the age of $3-5$ weeks and in the 12th week of life males were dinstinctly heavier than females. These differences are statistically significant for individuals of the spring generation $(P<0.001)$. This difference persisted to the end of the experiment. There are differences in the growth of individuals born in spring and autumn, but they are only faintly manifested and not always statistically significant (Table 1). Animals born in spring are heavier than those born in autumn. The predominance in body weight of the

Table 1

Body weight of spring- and autumn-born field voles at the age of 2,12 and 32 weeks. Average values \pm standard deviations are given.

\begin{tabular}{|c|c|c|c|c|c|}
\hline Age and sex & $\mathrm{n}$ & $\begin{array}{c}\text { Spring generation } \\
\text { Avg } \pm \text { SD }\end{array}$ & $\mathrm{n}$ & $\begin{array}{c}\text { Autumn generation } \\
\text { Avg. } \pm \mathrm{SD}\end{array}$ & Diff. \\
\hline \multicolumn{6}{|l|}{2 weeks } \\
\hline $\begin{array}{l}\text { Males } \\
\text { Females }\end{array}$ & $\begin{array}{r}7 \\
23\end{array}$ & $\begin{array}{l}8.36 \pm 2.06 \\
9.09 \pm 2.00\end{array}$ & $\begin{array}{r}7 \\
14\end{array}$ & $\begin{array}{l}6.94 \pm 1.30 \\
7.27 \pm 1.73\end{array}$ & NS \\
\hline \multicolumn{6}{|l|}{12 weeks } \\
\hline $\begin{array}{l}\text { Males } \\
\text { Females }\end{array}$ & $\begin{array}{l}23 \\
32\end{array}$ & $\begin{array}{l}27.92 \pm 5.72 \\
22.11 \pm 3.31\end{array}$ & $\begin{array}{l}13 \\
19\end{array}$ & $\begin{array}{l}22.96 \pm 3.84 \\
20.80 \pm 1.94\end{array}$ & $\begin{array}{r}S \\
\text { NS }\end{array}$ \\
\hline $\begin{array}{l}32 \text { weeks } \\
\text { Malees } \\
\text { Females }\end{array}$ & $\begin{array}{l}13 \\
18\end{array}$ & $\begin{array}{l}33.10 \pm 5.80 \\
26.92 \pm 5.74\end{array}$ & $\begin{array}{l}3 \\
7\end{array}$ & $\begin{array}{l}43.30 \pm 4.68 \\
30.76 \pm 5.89\end{array}$ & $\begin{array}{r}\mathrm{S} \\
\mathrm{NS}\end{array}$ \\
\hline
\end{tabular}

Difference: NS - Non significant; $\mathrm{S}$ - Significant, when tested with Student $t$ test for independent groups, at probability level 0.05 .

spring generation individuals was maintained to about the 28th week of life, when the situation was reversed and autumn generation individuals increased their body weight over the reached by spring generation individuals. Towards the end of the experiment the body weight of 30-34-week voles of both sexes in the autumn generation was far greater than in the spring generation, and differences in the case of males were statistically significant (Fig. 2, Table 1). 
Up to the $5-8$ week of life there is constant increase in the body weight of voles. In older voles, both on individual body curves of body weight and in mean values, it can be seen that periods of growth are interspersed with periods of both stabilization and reduction in weight. Periods of reduction in body weight occur in all individuals without exception. They may take place at different ages and their duration and frequency of repetition may differ. No sexual differences in these fluctuations were observed.

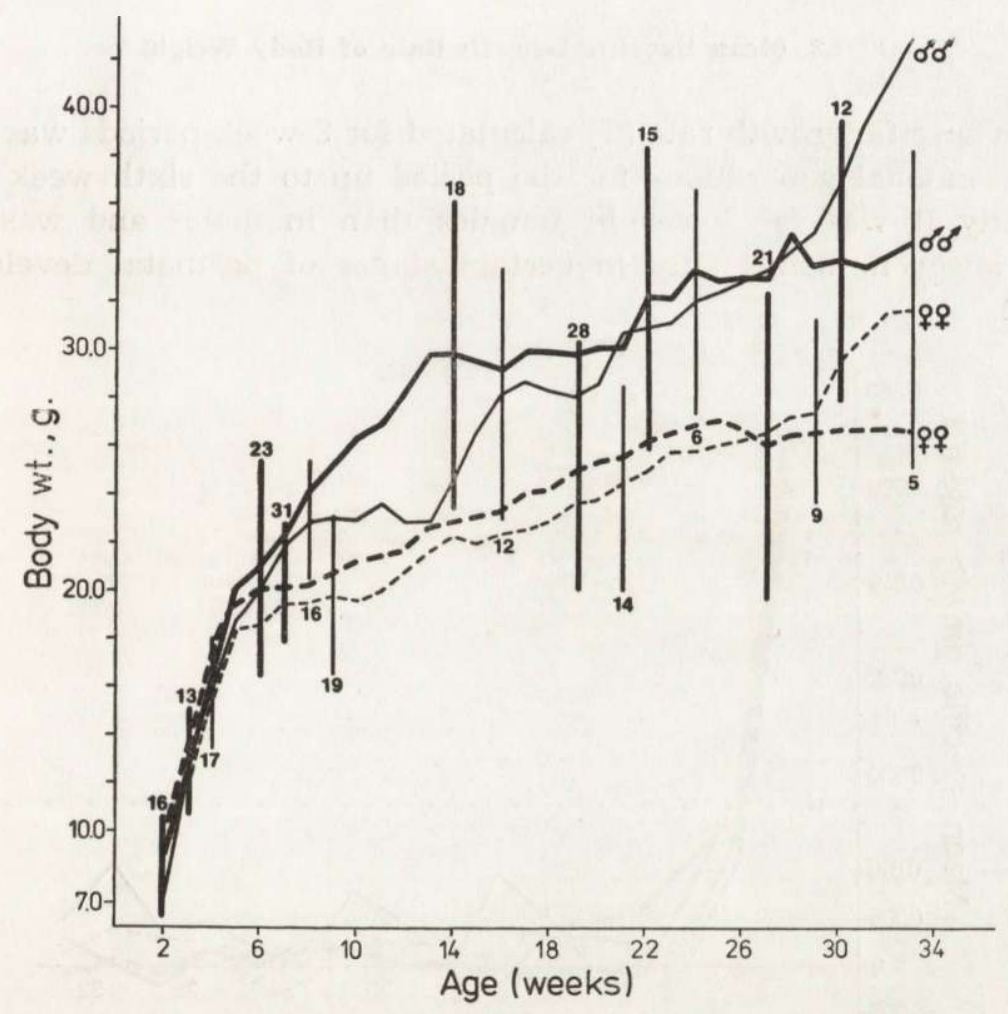

Fig. 2. Body weight growth curves of field voles of the spring (solid lines) and autumn (thin lines) generations. Standard deviations are shown by vertical lines, numbers above them (spring) or below (autumn) indicate the sample size.

In voles of both seasonal generations studied, older than 8 weeks, the continuous increase in body weight lasted $1-10$ (mode $=1)$ weeks, and the length of the period without increase in body weight was $1-6$ $($ mode $=1)$ weeks.

When comparison was made of curves of increase in body weight from the 2nd to 30 th week of life in 14 autumn and 20 spring voles, it was only possible to find that such growth and non-growth periods 
varied from $3-8$ (usually $5-6$ ). No differences were found in this respect between the seasonal generations.

The body weight of individuals from the same litter exhibited in many cases synchronous changes, e.g. only during a certain period of life, and in other periods it varied independently in different individuals. A groups of animals, matched for time of birth were chosen and their body weight compared. In no case were general regularities found regarding synchronization of growth of voles from these groups.

\subsection{Mean Specific Growth Rate of Body Weight}

Mean specific growth rate $(C)$ calculated for 2-week periods was similar in two seasonal generations for the period up to the sixth week of life. Generally it was far lower in females than in males and was equal to, or lower in males only in certain stages of postnatal development (Fig. 3).

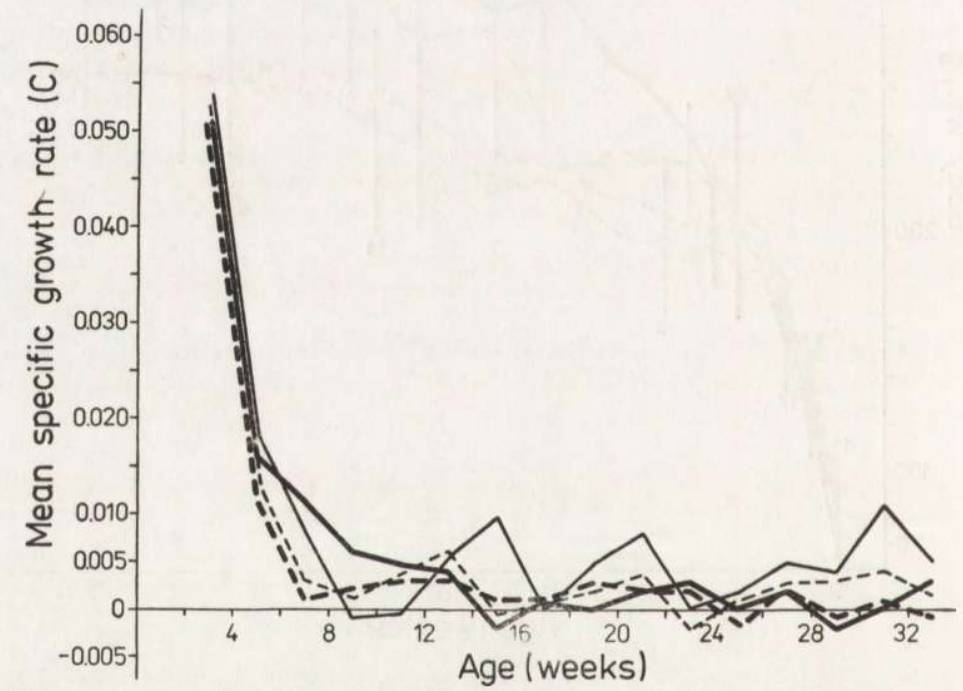

Fig. 3. Mean specific growth rate (C) of the body weight in spring (solid lines) and autumn (thin lines) field voles.

The growth rate of spring and autumn generation males was, practically speaking, equal up to the 7 th week of life, but later during the subsequent four weeks the autumn individuals grew more slowly than the spring individuals. After the 13th week of life their rate of growth increased and exceeded that of spring voles.

The growth rate of females of the two generations differed. After the first two weeks of life autumn generation females exhibited a higher 
growth rate, which was in principle maintained throughout the whole experiment.

The very great individual variation in growth rate and the relativel $y$ small differences in the growth of individuals of the two seasonal generations make it difficult to reveal differences between generation in the growth rate of individuals in these small samples.

\subsection{Effect of Tetracycline Injections on Body Weight}

Two out of 105 individuals given TH died directly after injection and one drastically decreased its body weight by half. Losses in body weight were found in $34 \%$ of the cases.

Comparison was made of body weight growth rate at the same age (in 2-week intervals) between individuals injected with $\mathrm{TH}$ or not injected (Table 2). It was only in two cases that the percentage of individual;

Table 2

Percentage of field voles showing negative specific growth rate of body weight among individuals of the same age group injected or not injected with tetracycline. Total number of individuals is given in brackets.

\begin{tabular}{|c|c|c|c|c|}
\hline \multirow{2}{*}{$\begin{array}{l}\text { Age in } \\
\text { weeks }\end{array}$} & \multicolumn{2}{|c|}{ Spring generation } & \multicolumn{2}{|c|}{ Autumn generation } \\
\hline & Injected & Non-injected & Injected & Non-injected \\
\hline $6-8$ & & & $33(3)$ & $15(26)$ \\
\hline $8-10$ & & & $75(4)$ & 35 (23) \\
\hline $12-14$ & 0 (5) & $17(24)$ & 0 (4) & 20 (15) \\
\hline $16-18$ & $80(5)$ & 30 (24) & & \\
\hline $18-20$ & & & $25(4)$ & 20 (15) \\
\hline $21-23$ & $0(5)$ & 31 (39) & 75 (4) & 30 (15) \\
\hline $43-45$ & $50(4)$ & & & \\
\hline $46-48$ & 60 (5) & 20 (10) & & \\
\hline $51-53$ & $40(5)$ & $20(5)$ & & \\
\hline
\end{tabular}

decreasing in body weight was similar in both generations, in two cases greater negative specific weight growth was found in non-injected animals and in six, injected animals. Among the 19 individuals decreasing in body weight after injection, in 12 lost weight before injection. No effect of tetracycline on body weight growth rate was shown.

\subsection{Skeleton Growth}

Relative increments of three bones, the mandible, femur and humerus of the same individual are similar in voles of both generations. In many cases relative increment of a certain bone may differ from the others. General comparisons show that the relative increment of the femur is usually the greatest and of the humerus lowest. 
Calculation was made of the degree of correlation of relative increments between the elements of the skeleton examined, and it was found that correlation coefficients are statistically significant and very high, the growth of skeletal elements being correlated to a greater degree in spring than in autumn voles (Fig. 4), that is, during the period of most intensive growth.

Mandible $\times$ Femur

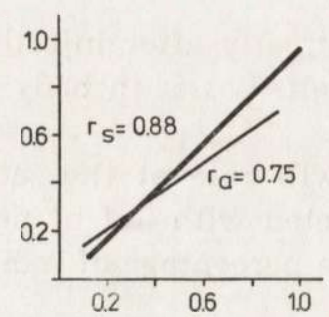

Mandible $\times$ Humerus Femur $\times$ Humerus

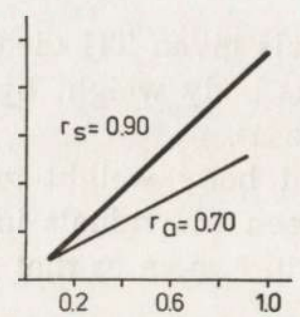

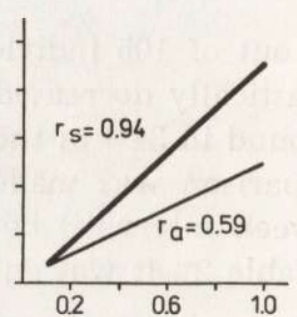

Fig. 4. Correlation of the relative bone increments in the study parts of the skeleton of spring-born (solid line) and autumn-born (thin line) field voles.! Correlation coefficients ( $r_{\mathrm{s}}$ for spring, $r_{\mathrm{a}}$ for autumn) are given.

\subsection{Sex Dimorphism in Skeleton Growth}

As there were only 4 or 5 individuals injected with $\mathrm{TH}$ in the given age group it was impossible to compare the mean bone increments of males and females. For this reason sex dimorphism was tested by comparing bone increments in pairs composed of a male and a female born the same day (in two cases date of birth differed by 1 day) and injected with TH simultaneously. No regularity at all was found in the character of sex dimorphism.

\subsection{Skeleton Growth in Voles of Different Seasonal Generations}

Increment in bone tissue during the 15 days after injecting $\mathrm{TH}$ is visible on bone ground sections viewed under ultraviolet light as the zone between the bright yellow fluorescent line of tetracycline and the margin of the bone. The absence of a TH-line in bones and its simultaneous occurrence in the incisors of injected individuals is evidence of the absence of skeleton growth at the time of injecting TH.

In the second month of life the skeleton growth index of spring individuals was almost twice greater than in autumn animals (Fig. 5). At the age of 3 months curves of skeleton growth rate intersect and the growth rate of autumn generation individuals becomes higher. At $4-6$ 


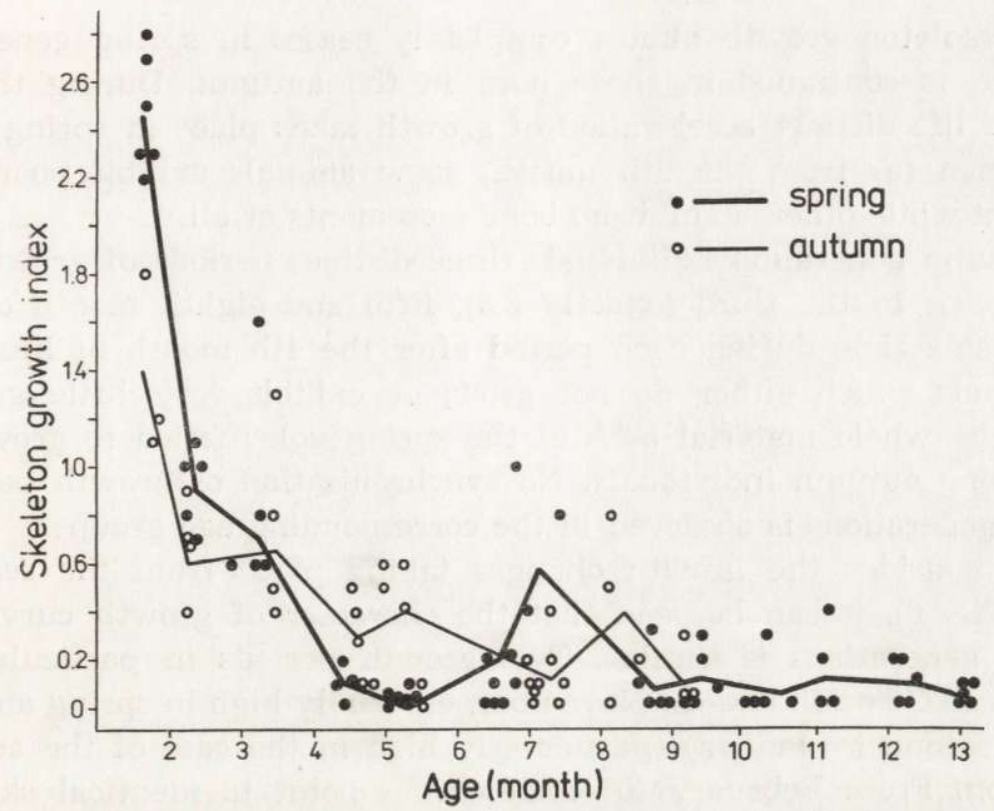

Fig. 5. Variation of the skeleton growth index with age in spring- and autumn-born field voles. Skeleton growth index is the total of relative bone increments estimated in all parts of the skeleton studied.

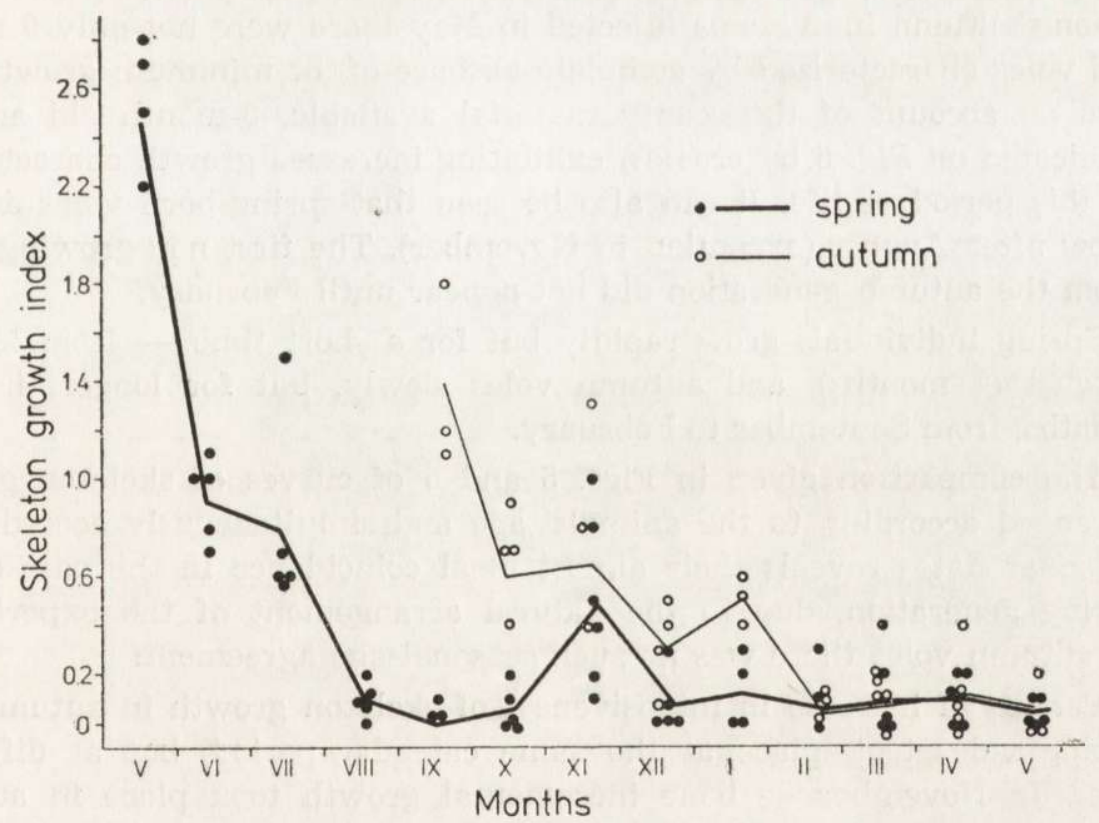

Fig. 6. Variation of the skeleton growth index during the course of the year in spring- and autumn-born field voles. Skeleton growth index is the total of relative bone increments estimated in all parts of the skeleton studied. 
months skeleton growth almost completely ceases in spring generation voles, but is continued in those born in the autumn. During the 7th month of life distinct acceleration of growth takes place in spring voles, after which (as from the 9th month) some animals exhibit poor bone increment while others exhibit no bone increments at all.

In autumn generation individuals three distinct periods of growth can be observed: in the third (exactly 3.5), fifth and eighth month of life. At the same time during each period after the 4th month of life there are animals which either do not grow, or exhibit very little growth. Among the whole material $50 \%$ of the spring voles failed to grow, and $20 \%$ among autumn individuals. No synchronization of growth between the two generations is observed in the corresponding age groups.

If we consider the growth changes taking place from the seasonal aspect (Fig. 6), it can be seen that the character of growth curves for the two generations is similar. Two growth periods in particular are synchronized. The first - in November, especially high in spring animals, and the second in January, particularly high in the case of the autumn generation. From February to April curves point to identical skeleton growth. In May a slight decline in growth rate is observed in spring voles in comparison with that in previous months, whereas in certain autumn individuals increase is considerable. This is due to the fact that among autumn individuals injected in May there were not only 9 month old voles characterized by complete absence of, or minimum growth, but also on account of the scanty material available, 8-month old animals (indicated on Fig. 6 by crosses) exhibiting increased growth characteristic of this period of life. It can also be seen that spring-born voles did not grow after August (exception in November). The first non-growing voles from the autumn generation did not appear until February.

Spring individuals grow rapidly but for a short time - from May to August (4 months), and autumn voles slowly, but for longer, i. e., 6 months, from September to February.

The comparison given in Figs. 5 and 6 of curves of skeleton growth arranged according to the animals' age and simultaneously according to calendar dates reveals their almost ideal coincidence in the case of the spring generation, due to the natural arrangement of the experiment. In autumn voles there was no such seasonal-age agreement.

Periods of increase in intensiveness of skeleton growth in autumn and spring voles took place at the same calendar period, but at different age 3. In November - bone incremental growth took place in autumn individuals at the age of 3.5 months, whereas in spring voles this occurred during the 7th month of life. In January growth was in autumn 5 month old and in spring 9 month old animals. 


\subsection{Skeleton vs Body Weight Growth}

Comparison of mean specific growth rate of body weight during the period which intervened between injection and killing the incividual (during a 15-day period) and of the skeleton growth index during this time in the same individual does not show any relation between them. High or low bone increment was found irrespective of change in body weight. No correlation was found between these parameters in either of the generations studied even during the period of intensive growth ( $2-8$ week of life).

\section{DISCUSSION}

In laboratory voles $M$. agrestis, kept under natural daylight conditions and on a diet differing slightly according to season, the general pattern of variations in body weight with age agreed with that described for other rodents. Differences in body weight growth in autumn and spring individuals were not, however, very great and were only evident when analysis was made of mean weights of the series of animals examined. They were smaller than in other species of voles (Pokrovskij \& Bolshakov, 1979) and in $M$. agrestis described by Bäumler (1979). They were also less distinct than those observed in this experiment between males and females. On the other hand, despite the small numbers in the different weight groups, distinct generation differences were revealed in skeleton growth.

It would seem that variability in weight or size of any part of the animal's body during its lifetime may be considered as a combination of the general growth trend common to all or many of the individuals in a sample (e. g. seasonal generation) and "disturbances" caused by the effect of a large number of different factors.

In analyzing growth of body weight we reveal a general growth trend as the trend of mean weights, possibly because disturbances from various directions cancel each other out. The greater such „disturbances” are in the growth curve of each individual - the greater the series of animals required to discover general tendencies within the group.

The skeleton, generally less subject to variation than body weight (Yablokov, 1974), would appear to be just such a system of the animal's organism in which age changes take place in accordance with the general trend, and "disturbances" may be of minimum importance. On this account it is possible to use fewer series of individuals to define general growth trend.

Analysis of skeleton growth rate showed that periods of intensified growth are interspersed with periods of its complete stabilization (growth 
retardation). Complete inhibition of growth during the winter period was not found in all the study animals. Individuals born in spring had a particularly low growth rate in winter, but among non-growing animals we also encountered growing individuals. This result differs from that obtained for mice of the genus Apodemus under natural conditions, when in 26 individuals given tetracycline in October and January no skeleton growth was found in any of the animals (Klevezal \& Mina, in print). These differences may be connected with the biological properties of voles and mice, and also with the conditions for the captive rodents' growth differing from natural ones. In this case temperature was similar in both summer and winter (not lower than $16^{\circ} \mathrm{C}$ ), and this may have been one of the factors conditioning skeleton growth. Under natural conditions low temperature in winter may possibly synchronize periods of growth cessation in all the individuals in the population.

Mstislavski (1938) distinguished exo- and endogenous influences on changes in body weight in a simple way. If in series of individuals differing as to period of birth similar changes in body dimensions occur at the same age, then they may be connected with the effect of endogenous factors, and if during the same calendar period - with the effects of exogenous factors.

When applying this method to analysis of changes in the body weight of field voles, no changes in growth rate were found common to all individuals of the same age or occurring during the same calendar period. In respect of skeleton growth however, two periods of growth acceleration were observed, taking place in individuals of the two seasonal generations during the same periods of the year - in November and January, but in animals of different age. This coincidence is particularly clearly expressed in the November growth intensification, which included all individuals of both generations. The January growth acceleration was not so distinct in spring born voles. In none of these periods were there any drastic changes in the food, illumination or temperature programs.

The third period of increase in growth intensiveness in autumn individuals took place in May, while spring voles either did not grow at all during this period, or grew only slightly. As the experiment ended during this period it is difficult to evaluate the character of such growth.

Thus despite the fact that it proved impossible to determine the causes of the occurrence of these periods of accelerated growth in the light of the data available, we consider that they are of an exogenous nature.

In addition to these distinct periods of synchronized growth, there are others manifested in individuals of the two generations asynchronously in relation to age and season. This is shown by the existence of nongrowing individuals during the whole experimental period, beginning 
with 4-month old spring individuals (August) and 5.5 month old animals of the autumn generation (February). These variations in growth cannot be classified as the result of the effect of endo- or exogenous factors, on account of the lack of appropriate data.

It may be said that the effect of tetracycline with the dose given on the growth rate of body weight has not been revealed. There are, however, indications that voles of the genus Microtus are more susceptible to tetracycline than are mice or rats (Stehn et al. 1980, Malafeeva in litt.), and therefore $\mathrm{TH}$ should be administered with care in different species.

Acknowledgements: Many thanks are due to Dr. M. V. Mina and Professor Z. Pucek for critical reading of the first draft of this paper, as well as to H. Bajko, I. Szpakowicz and N. V. Peremyslova for their technical assistance. Our thanks are extended to Dr. G. L. Dryden (Slippery Rock State College, Slippery Rock, $\mathrm{Pa}$. USA) for linguistic corrections of the text. This paper is the result of bilateral cooperation between the Mammals Res. Inst. of the Polish Academy of Sciences and N. K. Kolcov's Institute of Developmental Biology of the USSR Academy of Sciences.

\section{REFERENCES}

1. Adamczewska-Andrzejewska K., 1973: Growth, variations and age criteria in Apodemus agrarius (Pallas, 1771). Acta theriol., 18: 353-394.

2. Bäumler W., 1979: Ober den Einfluss von Winterungsfaktoren auf das Wachstum markierter Erdmäuse (Microtus agrestis L.). Anz. Schädlingsk., Pflanz. - u. Umweltschutz, 52: 4-10.

3. Hansson L. I., 1967: Daily growth in length of diaphysis measured by ? oxytetracycline in rabbit normally and after medullary plugging. Acta Orthop. scand., Suppl., 101: 1-199.

4. Klevezal G. A. \& Gębczyński M., 1978: Diurnal rhythm of the skeleton growth of some rodent species. Acta theriol., 23: 527-539.

5. Klevezal G. A. \& Mina M. V., 1980: A tetracycline method of group marking for rodents and prospect of its utilization in ecological studies. Zool. Ž., 59: 936-941 [In Russian with Engl. summ.].

5a. Mina M. V. \& Klevezal G. A., 1976: Rost životnyh. Analiz na urovne organizma. Izd. Nauka: 1-291. Moskva.

6. Mstislavski M., 1938: Metod postrojenia normalnoj krivoj rosta živogo organizma. Dokl. Akad. Nauk SSSR, 29: 462-464.

7. Pokrovskij A. V. \& Bolshakov B. N., 1979: Eksperimentalnaja ekologija polevok. Izd. Nauka: 1-147. Moskva.

8. Schmalhausen I. I., 1935: Opredelenije osnovnych poniatij i metodika isledovanija rosta. Sbornik: "Rost zivotnych" [The growth of animals. Ed. Kaplansky S. I. et al.]. Izd. Biomedgiz: 8-60. Moskva-Leningrad.

9. Schwarz S. S., Pokrovski A. V., Istschenko V. G., Olenjev V. G., Ovtschinnikova N. A. \& Pjastolova O. A., 1964: Biological pecularities of seasonal generations of rodents, with special references to the problem of senescence in mammals. Acta theriol., 8: 11-43.

10. Stehn R. A., Johnson E. A. \& Richmond M. E., 1980: An antibiotic rodenticide for pine voles in orchards. J. Wildlife Manage., 44: 275-280.

11. Yablokov A. V., 1974: Variability of mammals. Amerid Publ. Co.: $1-350$. New Delhi. 
12. Zejda J., 1971: Differential growth of three cohorts of the bank vole Clethrionomys glareolus, Schreb. 1780. Zool. Listy, 20: 229-245.

Accepted, October 15, 1983.

Galina A. KLEVEZAL, Michalina PUCEK i Evgenija P. MALAFEEVA

\section{WZROST CIAEA I SZKIELETU U LABORATORYJNYCH NORNIKOW BURYCH Z ROŻNYCH GENERACJI SEZONOWYCH}

\section{Streszczenie}

Celem pracy było prześledzenie i porównanie zmian ciężaru ciała i tempa wzrostu szkieletu $\mathrm{z}$ wiekiem u Microtus agrestis (Linnaeus, 1761) urodzonych w dwu różnych sezonach, wiosną $(n=66)$ i jesienią $(n=33)$, żyjących w dość stałych warunkach laboratoryjnych. Zwierzęta ważono raz $\mathrm{w}$ tygodniu. Co miesiąc 4-5 nornikom obydwu generacji podawano domięśniowo tetracyklinę w dawce $20 \mathrm{mg} / \mathrm{kg}$ wagi ciała i po 15 dniach usypiano, utrwalając materiał w $70 \%$ alkoholu etylowym.

Wzrost szkieletu określano na trzech kościach: żuchwie, kości udowej i ramieniowej. Na szlifach kostnych mierzono przyrosty tkanki kostnej, widoczne w ultrafioletowym świetle (Ryc. 1). Wyliczone wskaźniki przyrostu dla każdej kości sumowano, otrzymując wskaźnik wzrostu szkieletu poszczególnych osobników.

Srednie tempo przyrostu ciała (C) wyliczono jako tempo przyrostu w ciągu 2 tygodni wg formuły Schmalhausena dla przyrostów dobowych.

Olbrzymia zmienność indywidualna i wyraźny dymorfizm płciowy zacierają różnice występujące w ciężarze ciała osobników urodzonych wiosną i jesienią (Ryc. 2, Tabela 1). Zwierzęta urodzone wiosną, do około 28 tygodnia życia są cięższe w porównaniu z jesiennymi. Potem sytuacja ulega odwróceniu. U wszystkich osobników bez wyjątku, w różnym wieku obserwuje się okresy przyrostu i zmniejszania się ciężaru ciała. Nieprzerwany wzrost ciężaru ciała miał miejsce tylko do około 8 tygodni życia.

Ujawnienie różnic generacyjnych w tempie wzrostu ciężaru (C) wobec wielkiej zmienności indywidualnej $\mathrm{w}$ małej próbie jest trudne. $\mathrm{Na}$ ogół (C) było znacznie niższe u samic niż u samców. Samice generacji jesiennej miały tempo wzrostu wyższe niż samice generacji wiosennej (Ryc. 3).

Wskaźniki wzrostu wszystkich trzech kości wykazywały wysoki stopień skorelowania (Ryc. 4). W tempie wzrostu szkieletu istnieje wyraźne zróżnicowanie między generacjami, większe niż w przypadku masy ciała. Osobniki wiosenne rosną szybko ale krótko -4 miesiące, a jesienne wolno, ale dłużej -7 miesięcy (Ryc. 5). Okresy wzmożonego wzrostu szkieletu przeplatane są okresami stabilizacji. Nie stwierdzono wstrzymania wzrostu w okresie zimy. Akceleracja wzrostu szkieletu u osobników obydwu generacji wystąpiła w tych samych okresach roku - w listopadzie i styczniu, ale w różnym wieku norników (Ryc. 6). Trzeci okres zwiększonej intensywności wzrostu zaznaczył się u jesiennych norników w maju, podczas gdy wiosenne $w$ tym czasie nie rosły, lub rosły słabo. Wydaje się, że odpowiedzialnymi za akcelerację wzrostu mogą być czynniki egzogenne. 